\title{
Leaf Anatomy, Chemical Composition as Well as Essential Oils and their Antibacterial Activity of Some Lauraceous Taxa
}

\author{
Al-Safa H. Mohamed ${ }^{1 *}$, Wafaa Ahmed ${ }^{2}$, Einas Elshatoury ${ }^{3}$, Magdy M. \\ Mourad ${ }^{1}$
}

\author{
${ }^{1}$ Botany Department, Faculty of Science, Ain Shams University, Egypt. \\ ${ }^{2}$ Biology Department, Faculty of Science, Ban ghazi University, Libya Government. \\ ${ }^{3}$ Microbiology Department, Faculty of Science, Ain Shams University, Egypt. \\ * Corresponding author: Alsafa98@hotmail.com
}

\begin{abstract}
Eight taxa of Lauraceae representing four genera were subjected to the present study. The micro-morphological and chemical investigation were carried out according to traditional methods. The objective of the present study is to find criteria to facilitate the delimitation and identification of the taxa under investigation. The obtained leaf micro-characters were considered diagnostic at the generic and specific level. The extracted chemical compounds from the taxa under investigation ranged from 41-61. Most of tested oils showed antibacterial activity toward six bacteria strains. The most potent antibacterial oils were from Cinnamomum glanduliferum and $C$. verum. The antibacterial activity was due to oxygenated and non-oxygenated monoterpenes ( $\alpha$-pinene, $\beta$-pineneandcineole). The antibacterial activity of Apollonias barbujana is due to ( $\alpha$-phellandrene rather than cineole). The obtained data from an anatomical and chemical point of view can be considered diagnostic at the infraspecific level, but only to a certain extent.
\end{abstract}

Key words: Antibacterial activity, Essential oils, Lauraceae, Leaf Anatomy.

\section{Introduction}

The Lauraceae is one of the great economic and viable families of flowering plants .It contains about 2850 known species in 45 genera worldwide (Christenhusz and Byng, 2016), and is the most diverse family in the order Laurales. The family has two main centers of diversity, mostly in the tropical forests of Southeast Asia and South America,in addition to some disjuct genera as Laurus nobilis in the Mediterranean region, or in Macaronesia as Laurus azorica Franco, Ocoteafoetens (William Aiton) Baill. Perseaindica (L.) Spreng. and Apolloniasbarbujana (Cav.) Bornm. The family contains both aromatic evergreens and deciduous shrubs and trees.

In Lauraceae, oil cells containing oil drops are known as the primary site of essential oil biosynthesis, secretion and storage (Fahn, 1988). Oil cells are commonly present in roots,stem and fruit as well as leaves of the lauraceae (Metcalfe and Chalk, 1983; Baas and Gregory, 1985; Qinggang and Zhenghai, 1998). Most leaves of Lauraceae are simple, exstipulate and arranged alternately or whorled, with many ethereal oil cavities, causing many species to be aromatic and fragrant. Most also have ethereal secretory cells in their wood and bark (Rendle, 1952). The combination of macro and micro morphological investigation of leaf may well be supportive in taxonomic identification of some species in the family (Ceolin et al., 2009). Also, Faggetter, (1987); Moraes and Paoli (1999) reported that micromorphology of leaf epidermis are important in taxonomy of Lauraceae. The lamina is dorsiventral or bifacial, accordingly palisade developed more strongly than the adaxial. The mesophyll usually constitute specialized diagnostic feature of the family known as spherical ethereal secretors cells or that 


\section{Al-Safa H. Mohamed, Wafaa Ahmed, Einas El Shatoury, Magdy M. Mourad}

synthesize and store oil and mucilage substance (Metcalfe and Chalk, 1983). Secretory cells usually spherical with suberized wall and yellowish content; commonly giving rise to transparent dot in the leaf located in palisade and spongy and seldom in the lower epidermis as well (Metcalfe and Chalk, 1950). Minor leaf veins without phloem transfer cells are recorded in Cinnamomum, Laurus and Persea (Watson and Dallwitz, 1992).

The presence of secretory cells were found to be a marked anatomical feature of leaves in most of the species in Lauraceae (Chu and $\mathrm{Hu}, 1999)$. This is confirmed by investigation of the distribution density of oil cells, the morphology and structure of both oil and mucilage cells, and their localization in the mesophyll of 112 species, 5 varieties and 2 forms in 21 genera of lauraceae.

Phytochemicals in Lauraceae are numerous and diverse. Lauraceae trees are essential oil rich species(Gottlieb and Magalhães, 1960; Morais, 1972) viz. terpenoids, benzyl benzoates, allylphenols, and propenylphenols. Lignans and neolignans. Essential oils are composed of biologically active compounds (Milhau et al., 1997)and possess antibacterial, antifungal, antiviral, insecticidal and antioxidant properties (Burt, 2004; Kordali et al., 2005). The oil has shown various therapeutic actions (Lawless, 2013). Antimicrobial and antioxidanteffects are confirmed (Baratta et al., 1998).

The composition of the essential oil of different Cinnamomum species has been widely investigated. To cite but a few we can refer to (Jantan and Goh, 1990; Jantan and Goh, 1992; Jantan et al., 2003; Rana et al., 2009; Abdelwahab et al., 2010; Geng et al., 2011). The oils were found to contain cinnamaldehyde, linalool, camphor, terpinen4-ol and 1, 8-cineole, eugenol, safrole, cmuurolene, acadinol, germacrene $\mathrm{D}$, aterpineol, a-cadiene, 1, 6-octadien-3-ol,3,7dimethyl and 1-phenyl-propanr-2, 2-diol diethanoate as major compounds (Jantan and Goh, 1990; Jantan and Goh, 1992; Jantan et al., 2005; Abdelwahab et al., 2010).

In Egypt, cultivated Lauraceae are Apollonias barbujana, Cinnamomum camphora, C. glanduliferum, C. verum, Laurus azorica, L. nobilis, Persea americana var. armericana

and

P. americana var. drymifolia (Kamel and Loutfy, 2001). All are reported to have antibacterial activity (Derwish et al. 2009, Trajano et al. 2010, Su et al. 2012, Cosoveanu et al. 2013, Singh et al.., 2013, Boadi et al. 2015 ).

The aim of the present study is to examine the lamina micro characters and show how they can contribute to a certain extent, in the delimitation or identification between the taxa underinvestigation, as well as apreliminary survey on the chemicalcomposition of the essential oils to evaluate the inhibitory potentialof the essential oils against some pathogenic Gram positive and negative bacteria.

\section{Material and Methods}

Eight lauraceous taxa were collected from the Botanical Gardens of Ain Shams University (ASU) and Orman Botanical Garden (Egypt). The examined taxa representing four genera viz. Apollonias, Cinnamomum, Laurus and Persea including seven species, one subspecies and two varieties (Table, 1). The taxa under investigation were identified according to (Bailey, 1949 and Short, 1994)andthe voucher specimens were kept in CAIA (Herbarium of Botany Department, Faculty of science. Ain Shams University)

\section{Micro morphological investigation}

Lamina of the studied taxa were prepared using hand microtome at $10-20 \mu \mathrm{m}$. Then were double stained using safranin and light green and mounted in Canada balsam according to (Johansen, 1940)then, examined using BEL: B103T-PL light microscope. Photomicrographs were taken using digital camera (Canon power-shot A720, 8.0 mega pixels), the magnification power was expressed by $(\mathrm{x})$ at the Plant Taxonomy Research Laboratory, Botany Department, Faculty of Science, Ain Shams University, and Cairo, Egypt. The data of lamina anatomy were scored as binary code $(0,1)$. A dendrogram was constructed based on a distance using the Unweighted Pair Group Mean Arithmetic average (UPGMA).All calculations were performed with NTSYS-pc version 2.02 software package (Numerical Taxonomy System, Exeter Software) (Rohlf, 1990). 


\section{Al-Safa H. Mohamed, Wafaa Ahmed, Einas El Shatoury, Magdy M. Mourad}

\section{Essential oils extraction}

Fresh leaves of the examined taxa were submitted for $2 \mathrm{~h}$ to water- distillation using a Clevenger distillation apparatus (Clevenger-type) (Su et al., 2012) shown as following:

\begin{tabular}{ccc}
\hline Taxa & $\begin{array}{c}\text { Mass of } \\
\text { fresh } \\
\text { leaves, } \\
\text { Gram }\end{array}$ & $\begin{array}{c}\text { Yield of } \\
\text { essential oil, mg } \\
\text { (\% yield) }\end{array}$ \\
\hline $\mathbf{1}$ & 981 & $100(0.010 \%)$ \\
\hline $\mathbf{2}$ & 137 & $650(0.47 \%)$ \\
\hline $\mathbf{3}$ & 80.1 & $301(0.37 \%)$ \\
\hline $\mathbf{4}$ & 281.4 & $450(0.15 \%)$ \\
\hline $\mathbf{5}$ & 52.1 & $650(1.25 \%)$ \\
\hline $\mathbf{6}$ & 176.2 & $800(0.45 \%)$ \\
\hline $\mathbf{7}$ & 235.5 & $650(0.27 \%)$ \\
\hline $\mathbf{8}$ & 627.8 & $79(0.012 \%)$ \\
\hline
\end{tabular}

\section{Gas-chromatography-mass spectrometry (GC-MS) analysis}

Quantitative and qualitative analysis of the essential oil was done using a GC-MS (Model GC-2010 plus, SHIMAD24, Japan) at Faculty of Pharmacy, (ASU),Cairo, Egypt, equipped with a Rtx-5 MS(Cross bound 5\% diphenyl/95\% dimethyl polysiloxane capillary column $(30 \mathrm{~m} \times 0.25 \mathrm{~mm}$ i.d., film thickness $0.25 \mu \mathrm{m})$. For GC-MS detection, an electron ionization system with ionization energy of $70 \mathrm{eV}$ used. Helium gas used as a carrier gas at a constant flow rate of 1 $\mathrm{ml} / \mathrm{min}$. Injector and mass transfer (Interface) line temperature were set at 250 and $280^{\circ} \mathrm{C}$, respectively. Essential oils solution $(1 \mu \mathrm{l})$ in hexane was injected and investigated with the column held initially at $45^{\circ} \mathrm{C}$ for $2 \mathrm{~min}$ and then increased to $300^{\circ} \mathrm{C}$ with a $5^{\circ} \mathrm{C} / \mathrm{min}$ heating ramp and subsequently kept at $300^{\circ} \mathrm{C}$ for $5 \mathrm{~min}$. The major components of oils recognized by National Institute of Standards

Table 1: The studied taxa of Lauraceae and their taxonomic position as assigned according to Kostermans, (1957). ": similar

\begin{tabular}{|c|c|c|}
\hline Taxa & Tribe & Source \\
\hline $\begin{array}{l}\text { 1. Apollonias barbujana subsp. ceballosii } \\
\text { (Svent.) G.Kunkel Kanar Pflanzenw. } 157 \\
(1980)\end{array}$ & Perseae & $\begin{array}{l}\text { Bot. Gard. Fac. } \\
\text { Science ASU }\end{array}$ \\
\hline $\begin{array}{l}\text { 2. Cinnamomum camphora (L.) J.Presl } \\
\text { Prir. Rostlin 2: } 36 \text { ( 1825) }\end{array}$ & $\begin{array}{l}\text { Cinnamo } \\
\text { meae }\end{array}$ & Orman Bot. Gard. \\
\hline $\begin{array}{l}\text { 3. C. glanduliferum (Wall.) Meisn. Prodr. } \\
\text { 15(1): } 25.1864\end{array}$ & " & " \\
\hline $\begin{array}{l}\text { 4. C.verum J.Presl, Prir. Rostlin 292): } 36 . \\
1825\end{array}$ & " & " \\
\hline $\begin{array}{l}\text { 5. Laurus azorica (Seub.) Franco, } \\
\text { Inst. Super. Agron. 23: } 961960 .\end{array}$ & aureae & $\begin{array}{l}\text { Bot. Gard. Fac. } \\
\text { Education ASU }\end{array}$ \\
\hline 6. L. nobilis L., Sp. Pl. 1: 369. 1753 & " & $\begin{array}{l}\text { Bot. Gard. Fac. } \\
\text { Science ASU }\end{array}$ \\
\hline 7. Persea americana Mill. var. armericana & " & " \\
\hline $\begin{array}{l}\text { 8. P. americana Mill. var. drymifolia (Cham } \\
\text { \& Schltdl.) Mez, Jahrb. Königl. Bot. Gart. } \\
\text { Berlin 5: } 147 \text { 1889. }\end{array}$ & " & " \\
\hline
\end{tabular}




\section{Al-Safa H. Mohamed, Wafaa Ahmed, Einas El Shatoury, Magdy M. Mourad}

Technology (NIST) V.11 GC-MS library, established by(Adams, 2007) and previous studies on different species of Lauraceae. The relative concentration of each compound in essential oils counted based on the peak area integrated by the analysis program $(\mathrm{Su}$ et al., 2012).

\section{Antibacterial activity \\ Bacterial strains used}

The antibacterial assay was carried out at the Regional Center of Mycology and Biotechnology at Al Azhar University, Cairo, Egypt. Six bacterial pathogens strains used viz. Streptococcus pneumoniae (RCMB 010010), Staphylococcus aureus (RCMB 010027),

Methicillin-Resistant Staphylococcus aureus (MRSA 2658 RCMB), Pseudomonas aeruginosa (RCMB010043), Escherichia coli (RCMB010052) and Klebsiella pneumoniae (RCMB 0010093 (12)

\section{Determination of the minimum inhibitory concentration (MIC)}

The microbial suspension equivalent to the turbidity of $0.5 \mathrm{McFarlan}\left(10^{8} \mathrm{CFU} / \mathrm{ml}\right)$ standard was prepared from a fresh subculture of tested bacteria in Muller Hinton Broth (MHB) then this suspension was diluted to $10^{6} \mathrm{CFU} / \mathrm{ml}$. The adjusted microbial inoculum $(100 \mu \mathrm{l})$ were added to each 96-well flat-bottomed microtiter plate containing the tested concentration of tested samples $(100 \mu 1 /$ well). As a result, last inoculum concentration of $5 \times 10^{5} \mathrm{CFU} / \mathrm{ml}$ was obtained in each well. Three wells containing microbial suspension with no sample using Dimethylsulfoxid DMSO employed for dissolving the tested compound (Growth control) and two wells containing only media (background control) were included in this plate. Optical densities were measured after 24 hours at $37^{\circ} \mathrm{C}$ using a multi-detection micro plate reader at The Regional Center for Mycology and Biotechnology (Sun Rise-Tecan, USA) at $600 \mathrm{~nm}$. Ampicillin, Vancomycine and Gentamicin were used as standards for (Streptococcus pneumoniae, Staphylococcus aureus), Methicillin-Resistant Staphylococcus aureus (MRSA) and
Pseudomonas aeruginosa, Escherichia coli and Klebsiella pneumoniae.

For the determination of MIC of tested samples by the micro-broth kinetic assay, the percentage of growth at each sample concentration was calculated with the following equation: [(OD600 of wells containing the sample/OD600 of the samplefree well) $\times 100]$ after subtraction of background ODs (ODs of microorganismfree wells) according to(Esma Gündüz et al., 2009).

\section{Results and discussion}

\section{Lamina anatomical characters}

Lamina anatomical characters of the studied taxa (34 characters) are summarized in Table (2) and illustrated in plate (I). Adaxial epidermal cells are radially arranged as in Cinnamomum verum and Laurus nobilis; radially/tangentially as in Apollonias barbujana, Cinnanomum camphora, Persea americana var. armericana and Persea americana var. drymifolia or papillose as in Cinnamomum glanduliferum and Laurus azorica. Abaxial epidermis are radially as in Persea .americana var. armericana and P. americana var. drymifolia; radially /tangentially as in Apollonias barbujana, Laurus nobilis or papillose as in Cinnamomum camphora, C. glanduliferum, C. verum and Laurus azorica. Cuticle thin as in Persea americana var. armericana and $P$. americana var. drymifolia or thick in the rest of the studied taxa. Hypodermis detected in Laurus azorica, L. nobilis, Persea Americana var. armericana and $P$. americana var. drymifolia or wanting in the rest of the studied taxa. Trichomes are eglandular unicellular at abaxial surface as in Persea Americana var. armericana and $P$. americana var. drymifolia or wanting in the rest of the studied taxa.

Mesophyll is dorsiventral in all the taxa under investigation. Palisade tissue are elongated as in Cinnamomum verum, Persea americana var. armericana and $P$. americana var. drymifolia or cubic in the rest. Palisade tissue are 1-2 rows as in Cinnamomum verum, one row as in Persea americana var. americana, two rows as in Cinnamomum glanduliferum and Persea 


\section{Al-Safa H. Mohamed, Wafaa Ahmed, Einas El Shatoury, Magdy M. Mourad}

americana var. drymifolia; 2-3 rows as in Cinnamomum camphora; three rows as in Apollonias barbujanaor 3-4 rows as in Laurus azorica and L. nobilis. Rows of spongy tissue are 5-6 rows as in Persea americana var. americana; 3-4 rows as in $P$. americana var drymifolia, or 4-5 rows of the rest of the studied taxa.

Palisade tissue extended at mid rib region as in Persea americana var. armericana and P. americana var. drymifolia or wanting in the rest of the studied taxa. Collenchyma; lamaller as in Cinnamomum camphora and C.glanduliferum; annular as Persea americana var. armericana and $P$. americana var. drymifolia or angular lamaller in the rest of the studied taxa. The vascular supply shows continuous siphonostele in all the studied taxa. Vascular system is kidney as in Persea americana var. armericana and $P$. americana var. drymifolia or cresentiform in the rest of the studied taxa.

The obtained anatomical characters indicate that the existence of secretory cells obviously difference of their distribution density among the species in lauraceae. Secretory cellssolitary, isolatedor bigger than the adjacent cells and are present in all taxa in wing region. The highest number were recorded in Apollonias barbujana, Laurus azorica and L. nobilis, while the lowest number are scored in the rest of the studied taxa.

In Apollonias barbujana the secretory cells were detected at mid-rib region. Regarding the phloem tissue and secretory cells, these were scored in Laurus azorica and L.nobilis, or absent in the rest of the studied taxa.The presence of secretory cells containing oil or mucilage in all taxa constitutes one of the most important characteristic features of Lauraceae. According to Metcalfe and Chalk (1979), it was recorded in the leaf of all investigated species belonging to different genera of the family.

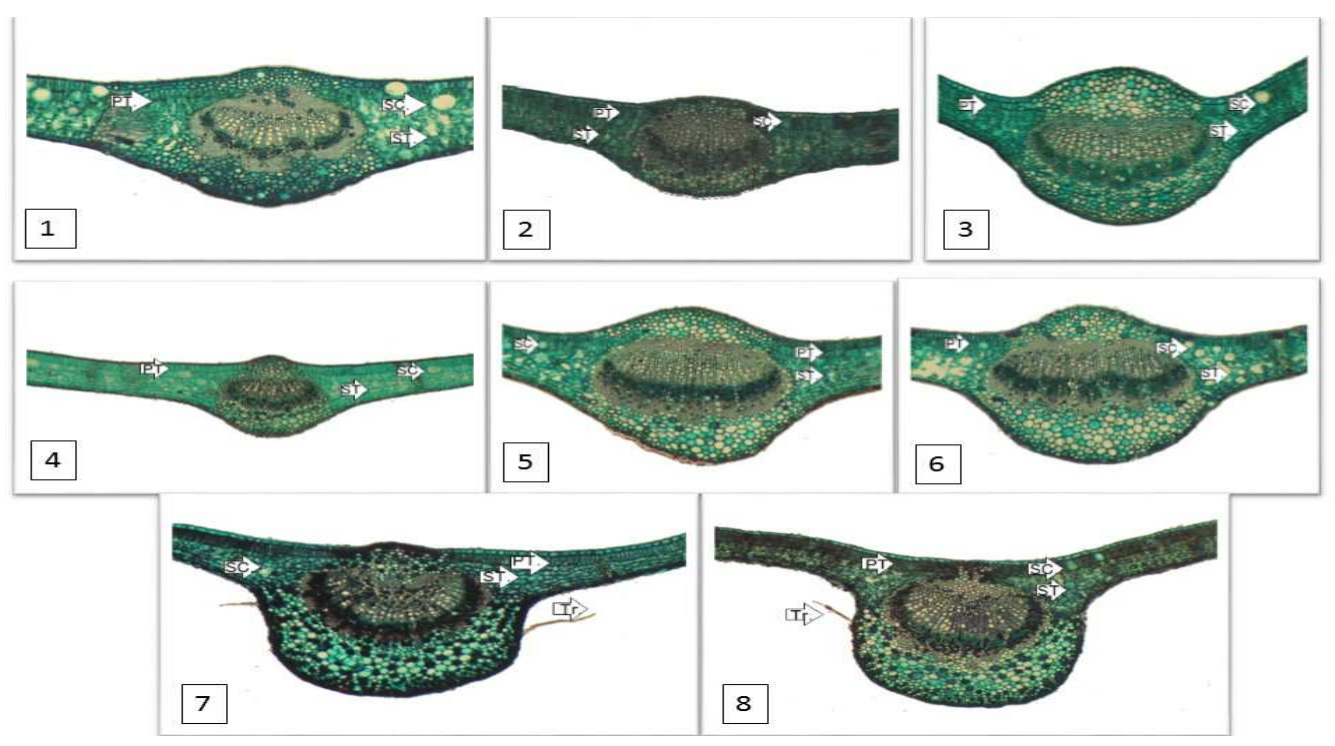

Plate 1: text figs 1-8. Lamina micrographs of the studied taxa of Lauraceae:

1: Apollonians barbujana; 2: Cinnamomum camphora; 3: C. glandiferum; 4: C. verum; 5: Laurus azorica; 6: L. nobilis; 7: Persea armericana var. armericana 8: P. armericana var. drymifolia. Secretory cells (SC), Palisade tissue (PL), Spongy tissue (SP), Trichomes (Tr) not indicated on the graphs, $(\mathrm{X}=10)$. 


\section{Al-Safa H. Mohamed, Wafaa Ahmed, Einas El Shatoury, Magdy M. Mourad}

Table 2: Lamina anatomical Characters of the Studied Taxa, (+): Present; (-): Absent; ("): Similar;

$(\mathrm{Ad})$ : Adaxial surface; $(\mathrm{Ab})$ : Abaxial surface

\begin{tabular}{|c|c|c|c|c|c|c|c|c|c|c|c|c|}
\hline \multirow{3}{*}{$\begin{array}{c}\dot{\dot{Z}} \\
\substack{\tilde{Z} \\
\tilde{\sigma} \\
\tilde{\sigma}}\end{array}$} & \multirow{3}{*}{ 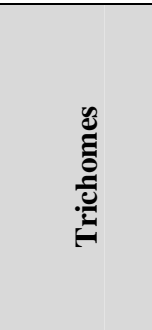 } & \multicolumn{4}{|c|}{ Dermal System } & \multicolumn{3}{|c|}{ Mesophyll Tissue } & \multirow{3}{*}{\begin{tabular}{c}
$\begin{array}{c}\text { Mechani } \\
\text { cal } \\
\text { Tissue }\end{array}$ \\
\\
\multirow{3}{*}{}
\end{tabular}} & \multicolumn{2}{|c|}{ Secretory cells } & \multirow{3}{*}{$\begin{array}{c}\begin{array}{c}\text { Vascular } \\
\text { Tissue }\end{array} \\
\text { ๘ } \\
\text { ळ }\end{array}$} \\
\hline & & \multicolumn{2}{|c|}{$\begin{array}{l}\text { Epidermal cell } \\
\text { arrangement }\end{array}$} & \multirow[b]{2}{*}{ 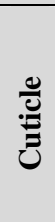 } & \multirow{2}{*}{ 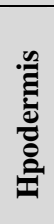 } & \multirow{2}{*}{ 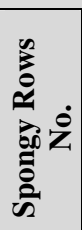 } & \multirow{2}{*}{ 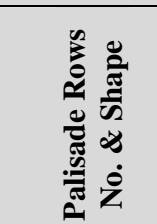 } & \multirow{2}{*}{ 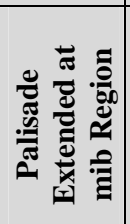 } & & \multirow{2}{*}{$\frac{\grave{\Xi}}{\grave{\Xi}}$} & \multirow{2}{*}{ 氜 } & \\
\hline & & 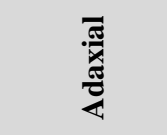 & 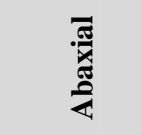 & & & & & & & & & \\
\hline 1 & - & $\begin{array}{c}\text { Radially- } \\
\text { Tangentiall } \\
\text { y }\end{array}$ & $\begin{array}{l}\text { Radially- } \\
\text { Tangentia } \\
\text {-lly }\end{array}$ & $\frac{\stackrel{y}{\circlearrowright}}{\stackrel{\Xi}{E}}$ & - & $4-5$ & 3 Cubic & - & $\begin{array}{l}\text { Lamellar` } \\
\text { angular }\end{array}$ & $\begin{array}{l}\text { More } \\
\text { than } 3\end{array}$ & $\begin{array}{l}\text { Midrib } \\
\text { Wing }\end{array}$ & Crescentiform \\
\hline 2 & - & $\begin{array}{c}\text { Radially- } \\
\text { Tangentiall } \\
\mathrm{y}\end{array}$ & Papillose & $=$ & - & $"$ & $2-3$ Cubic & - & $"$ & 3 or less & Wing & $"$ \\
\hline 3 & - & Papillose & $"$ & $=$ & - & $"$ & $2-$ Cubic & - & Lamellar & $"$ & $"$ & $"$ \\
\hline 4 & - & Radially & $"$ & $=$ & - & $"$ & $\begin{array}{c}1-2 \\
\text { Elongated }\end{array}$ & - & $"$ & $"$ & $\begin{array}{c}\text { Phloem } \\
\text { Wing }\end{array}$ & $"$ \\
\hline 5 & - & Papillose & $"$ & $=$ & + & $"$ & 3-4 Cubic & - & 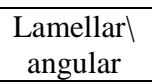 & $\begin{array}{l}\text { More } \\
\text { than } 3\end{array}$ & " & $"$ \\
\hline 6 & - & Radially & $\begin{array}{c}\text { Radially- } \\
\text { Tangentia } \\
\text {-lly }\end{array}$ & $=$ & + & $"$ & $"$ & - & $"$ & $"$ & Wing & $"$ \\
\hline 7 & $\begin{array}{l}\text { Ab- } \\
\text { Eglandular } \\
\text { unicellular }\end{array}$ & $\begin{array}{c}\text { Radially- } \\
\text { Tangentiall } \\
\text { y }\end{array}$ & Radially & $\stackrel{\Xi}{E}$ & + & $5-6$ & $\begin{array}{c}1- \\
\text { Elongated }\end{array}$ & + & Annular & $"$ & $"$ & Kidney shaped \\
\hline 8 & $\begin{array}{c}\text { Ab- } \\
\text { Eglandular } \\
\text { unicellular }\end{array}$ & $\begin{array}{c}\text { Radially- } \\
\text { Tangentiall } \\
\text { y }\end{array}$ & Radially & $=$ & + & $3-4$ & $\begin{array}{c}2- \\
\text { Elongated }\end{array}$ & + & $"$ & $"$ & $"$ & $"$ \\
\hline
\end{tabular}




\section{Al-Safa H. Mohamed, Wafaa Ahmed, Einas El Shatoury, Magdy M. Mourad}

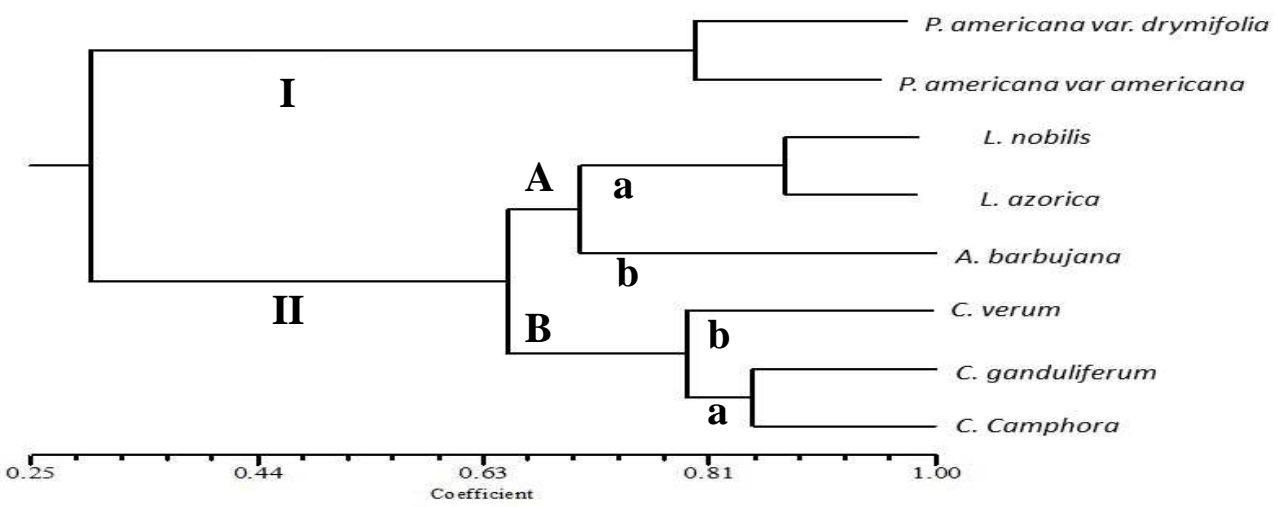

Fig. 1. UPGMA-dendrogram based on 34 revealed attributes from lamina micrograph

The lamina anatomical criteria of the taxa under investigation show a great homogeneity or close relationships at specific level amongst them these remark was supported by the dendrogram revealed from 34 lamina anatomical characters (fig 1).

Two main series are recorded series I includes Persea americana var. americana and $P$. americana var. drymifolia at similarity level $80 \%$. Series II has two clusters A \& B. Cluster A is differentiated into two groups a \& b. Group a contains Laurus nobilis and L. azorica at similarity level 88\%. Group b contains Apollonias barbujana. Cluster B is differentiated into two groups a \& b. Group a includes Cinnamomum glanduliferum and $C$. camphora at similarity level $85 \%$. Group b contains $C$. verum. This is in agreement with (Kostermans, 1957), who allocated taxonomic position of Cinnamomum spp. in tribe Cinnamomeae and Laurus spp. in tribe Laurceae. Lamina anatomical characters facilitate the construction of an artificial key to differentiate between the studied taxa:

A.Trichomes present, Kidney shaped V.B., Palisade extended at midrib

B. Spongy rows 5-6.

Persea americana var. americana

BB. Spongy rows 3-4 P.americana var. drymifolia

AA.Trichomes absent, Crecentiform shaped V.B., Palisade not extended at midrib

C. Elongated palisade Cinnamomum verum

CC. Cubic palisade

D. Collenchyma lamellar.

C. glanduliferum

DD. Collenchyma lamellar angular

E. Hypodermis present

F. Papillose epidermis (ad \&abaxially)

Laurus azorica

FF. Radially adaxially, Radially- Tangentialy abaxially epidermis................... nobilis

EE.Hypodermis absent

G. Location of secretory cells at midrib and wing. Apollonias barbujana

GG. Location of secretory cells at wing. Cinnamomum camphora

The anatomical difference among the studied taxa observe affinity between taxa and support the position of almost taxa under the specific tribes as cited by (Kostermans, 1957). Moreover, there is a highlight on the lamina anatomy as suggested by many taxonomists. Hussin et al., (1992); Rudall
(1994) claimed that the leaf anatomy play significant role in the systematics of certain families. Special structure of secretory cell, difference of number and distribution are useful in the differentiation among species by the presence or absence of secretory cell in phloem, midrib of the lamina, this result is 


\section{Al-Safa H. Mohamed, Wafaa Ahmed, Einas El Shatoury, Magdy M. Mourad}

confirmed in the present study. However, further studies are necessary to understand the structure of secretory cells.

\section{Gas-chromatography-mass spectrometry (GC-MS) analysis}

The essential oils of eight taxa were analyzed usingGC-MS chromatography. The detected compounds ranged from 41 to 65 compound (Table, 3). In the essential oil of Apollonias barbujana 53 compounds were identified. The main components viz. $\alpha$ phellandrene $(31.01 \%)$; butyl acetate $(16.20 \%)$; trans-beta-ocimene $(7.54 \%)$; pcymene $(4.96 \%)$ or caryophyllene $(4.96 \%)$. Forty eight components were identified in the essential oil of Cinnamomum camphora. Camphor was the main component in $(59.22 \%)$ while butyl acetate (21.96\%); cineole $(20.49 \%)$; $\beta$-phellandrene $(15.06 \%)$; isobutyl acetate $(6.21 \%)$ or toluene $(4.13 \%)$ were the dominant constituents in $C$. glanduliferum out of 41 compounds were identified. Forty eight components were identified in the essential oil of $C$. verum. The main component were butyl acetate (15.27\%); cineol (20.12\%); $\alpha$-phellandrene (13.06 \%); isobutyl acetate $(5.65 \%)$ or camphor $(5.14 \%)$. Fifty one compounds were identified in Laurus azorica oil. The major constituents were cineol (29.30\%), butyl acetate $(17.91 \%)$ or $\alpha$-terpinyl acetate $(9.61 \%)$, while in Laurus nobilis 65 components were identified. The main components were cineol (29.32\%); linalool (15.78); camphor (15.67\%) and $\alpha$-terpinyl acetate $(7.11 \%)$. In Persea americana var. americanat he essential oil contains 49 compounds where estragol $(81.32 \%)$ was the main component, while in $P$. americana var. drymifolia 64 compounds were identified, butyl acetate $(26.31 \%)$; $\alpha$-terpinyl acetate (13.39\%) and isobutyl acetate (7.53\%) were the major constituents.

In laurel leaf oil, six major compounds were common in all of the studied taxa viz.butyl acetate; $\alpha$-pinene; $\beta$-pinene; toluene; norbornane or cyclopentane ethyl.

Oils of the taxa under investigation were dominated by oxygenated and nonoxygenated monoterpenes as detected in Apollonias barbujana (51.15\%); C. camphora (72.49\%); Cinnamomum glandiferum (52.55\%); C. verum $(54.23 \%)$; Laurus azorica (48.1\%); L. nobilis (76.57\%); Persea americana var. americana $(86.74 \%)$ and in P.americana var. americana (13.9\%).

Non-oxygenated monoterpenes; mcymene detected in Laurus azorica and $L$. nobilis. P-cymene detected in all taxa except Persea americana var. americana and P.americana var. drymifolia. $\beta$-phellandrene present in all taxa except Cinnamomum camphora and Persea amerinaca var. americana, $\alpha$ - phellandrene detected in high concentration in Apollonias barbujana and Cinnamomum verum. Myrecene detected in all taxa expect Persea americana var. americana. D-limonene detected in all taxa except Apollinia barbujana, Cinnamomum glanduliferum and Persea americana var. drymifolia. Trans-beta-ocimene and cis-betaocimene detected in Apollinia barbujana and Persea americana var.americana. Cisbeta-ocimene detected in Laurus nobilis. $\gamma$ terpinene detected in Cinnamomum glanduliferum, C. verum, Laurus azorica and L. nobilis.

For oxygenated monoterpenes: linalool detected in Apollinias barbujana, Laurus azorica, L. nobilis and Persea americana var.drymifolia. Camphor detected in Cinnamomum camphora, C. verum, Laurus nobilis and Persea americana var. drymifolia. Terpinen-4-ol detected in all taxa except Apollonias barbujana and Persea americana var. americana. $\alpha$-terpineol detected in all taxa except Apollonias barbujana and Cinnamomum camphora. Estragole detected in Apollonias barbujana, Cinnamomum verum and Persea americana var. drymifolia. These data are in agreement with the previous work of (Brophy et al., 2001; Setzer et al., 2007; Takaku et al., 2007; Palazzo et al., 2009).

The taxa under investigated recorded low concentration of sesquiterpenes. The most common non-oxygenated sesquiterpenes were caryophyllene detected in all taxa except Cinnamomum glanduliferum and Laurus azorica; germacrene D detected in Apollonias barbujana, C. verum, Laurus azorica and P.americanavar.drymifolia or germacrene B detected in Cinnamomum. verum, L. nobilis 


\section{Al-Safa H. Mohamed, Wafaa Ahmed, Einas El Shatoury, Magdy M. Mourad}

and Persea americana var.americana. Caryophyllene oxide (oxygenate sesquiterpene) detected in Apollonias barbujana, Laurus nobilis, Persea americana var. americana and P.americana var. drymifolia. These data are in harmony with the previous work of (Brophy et al., 2001; Setzer et al., 2007; Takaku et al., 2007; Palazzo et al., 2009).

The variation in the essential oils components could be attributed to geographical origin, seasonal maturity, genetic variation, growth stages, part of plant utilized and postharvest drying and storage which may influence the essential oil composition(Marotti et al., 1994; Hussain et al., 2008; Anwar et al., 2009). Furthermore, climatic factors such as heat and drought were also play role in essential oil profiles (Milos et al., 2001). In addition, pointed out that altitude seems to be another important environmental factor influencing the essential oil content and chemical composition.

\section{Antibacterial activity}

The laurel essential oils of the studied taxa were capable of inhibiting the growth of the tested bacteria viz. Streptococcus pneumoniae, Staphylococcus aureus (two strains), Escherichia coli and Klebsiella pneumoniae. On the other hand, Pseudomonas aeruginosa was resistant to essential oil of the studied taxa. Similar results were indicated earlier for essential oils extracted from Cinnamomum verum (Trajano et al., 2010), Larus azorica (Cosoveanu et al., 2013), L. nobilis (Goudjil et al., 2015), and Persea americana (Boadi et al., 2015). The resistance of $P$. aeruginosa might be attributed to the frequent appearance of antibiotic resistant genes among $P$. aeruginosa which is always involved in hospital infection (Mann et al., 2000).

\section{Determination of MIC of tested plant oils}

The minimum inhibitory concentration (MIC) is defined as the lowest concentration of an antimicrobial agent that will inhibit the visible growth of a microorganism after overnight incubation (appendix). Among all oils analyzed, in this work, the essential oil of Cinnamomum was the most effective as an antibacterial agent followed by Laurus.

The essential oil of Cinnamomum glanduliferum was the most efficient antibacterial agents used, as it inhibited five tested bacteria at low (minimum inhibitory) concentration.

Although (Singh et al., 2013) reported that essential oil of $C$. glanduliferm leaves inhibited the growth of all tested bacteria, the concentration required to inhibit the growth was relatively higher than that recorded in this study.

The second most efficient oils of $\mathrm{C}$. verum showed strong activity against the five tested bacteria. The least MIC recorded was against Staphylococcus aureus and Escherichia coli which were inhibited by $0.98 \mu \mathrm{g} / \mathrm{ml}$. (Trajano et al., 2010) reported similar results were $S$. aureus and E.coli were inhibited by low concentration of essential oil from Cinnamomum verum.

The strong activity of oils from $C$. glanduliferm and $C$. verum is due to the presence of chemical compounds recognized for their antibacterial efficiency: cineole has been known to exhibit antibacterial activity against the bacterial strains of E. coli, Pseudomonas aeruginosa, Salmonella typhi, S. aureus, $S$. intermedius and Bacillus subtilis(Sivropoulou et al., 1997). Cineole has anti-inflammatory, antimicrobial and antitumor properties (Santos and Rao, 2000; Hiroyuki Moteki et al., 2002).

Although camphor is well known as antibacterial agent, its presence in high concentration $(59.22 \%)$ in Cinnamomum camphora was not accompanied by strong antibacterial activity. C. camphora showed low activity against the five tested bacteria. Higher concentrations ranging from 31.25$125 \mu \mathrm{g} / \mathrm{ml}$ were required to inhibit the tested organisms. Similarly (Su et al., 2012) noted that higher concentrations of essential oil of C. camphora were required to inhibit the tested bacteria (Staphylococcus aureus, Escherichia coli and Pseudomonas aeruginosa ). Earlier studies on the antibacterial effects of essential oils of $C$. camphora attributed the inhibitory effects of 


\section{Al-Safa H. Mohamed, Wafaa Ahmed, Einas El Shatoury, Magdy M. Mourad}

oils to chemical constituents that include limonene, $\beta$-phellandrene, $\alpha$-phellandrene, $\gamma$ terpinene, B-caryophyllene and $\alpha$-pinene (Koheil, 2000; Nirmal et al., 2005; Guibo et al., 2008).

Laurus azorica had strong activity against Klebsiella pneumoniae, Staphylococcus aureus and Escherichia coli with MIC of $1.95,3.9$ and $7.81 \mu \mathrm{g} / \mathrm{ml}$ respectively. Cosoveanu et al. (2013) reported that Lasurus azorica had strong activity against Escherichia coli.

Laurus nobilis and Apollinias barbujana were similar in MIC and inhibited Streptococcus pneumoniae, Staphylococcus aureus and Escherichia coli at concentrations $31.25,15.63$ and $15.63 \mu \mathrm{g} / \mathrm{ml}$ respectively. Laurus nobilis was extensively studied compared to other plants. Klebsiella pneumoniae is more sensitive to essential oils of Laurus nobilis than the other bacterial strains tested, with a MIC $(1.95 \mathrm{mg} / \mathrm{ml})$. These results were in agreement with Goudjil et al. (2015) who concluded that strains of Gram Negative Salmonella enterica and Klebsiella pneumoniae are more sensitive than the other bacterial strains tested. On the other hand Derwich et al., (2009) concluded that Staphylococcus aureus is more sensitive to essential oil of Laurus nobilis than Klebsiella pneumoniae.

The antibacterial activity of both varieties of Persea americana were the same, they have antibacterial activity against only two bacteria (Klebsiella pneumoniae and Escherichia coli) with MIC 31.25 and $62.5 \%$ respectively. (Boadi et al., 2015) found that chloroform extract of Persea americana leaves inhibited Escherichia coli but had no activity against Staphylococcus aureus. The role of cineol in the antibacterial activity could be confirmed by the observation that Laurus azorica and L. nobilis which had high concentration of cineol, and had strong antibacterial activity. Similar conclusion was demonstrated by Derwich et al., (2009), Elharas et al., (2013) who detected that antimicrobial action of cineol can be attributed to its high level of mono oxygenated terpenes. . Cineole is also known for its antibacterial power to fight against several bacterial strains tested. Moreover, both varieties of Persea americana which had low concentration of cineol, had no activity against most tested bacterial strains. Apollonias barbujanas showed anti-bacterial activity against tested bacteria, this could be attributed to high concentration of $\alpha$ phellandrene that was present in high concentration.

The action mechanism of oxygenated and hydrocarbon terpenes (eg. $\alpha$-pinene, $\beta$ pinene, $\mathrm{p}$-cymene, linalool and 4-terpineole) found in members belonging to Cinnammoum in different parts of world, is believed to be due to accumulation in the bacterial membrane which cause loss of membrane integrity, leakage of cytoplasmic content dissipation of proton motive force, cell lysis, and cell death (Sikkema et al., 1994) and (Gustafson et al., 1998).

Further study might include studying the antibacterial activity of particular fraction (s) of the essential oils of plants with potential activity and studying the mechanism of inhibition. 


\section{Al-Safa H. Mohamed, Wafaa Ahmed, Einas El Shatoury, Magdy M. Mourad}

Table 3: Minimum inhibitory concentration $(\mu \mathrm{g} / \mathrm{ml})$ of the essential oils of the studied taxa of Lauraceae leaves on different pathogenic bacterial strains

\begin{tabular}{|c|c|c|c|c|c|c|c|c|c|}
\hline \multirow{2}{*}{ Essential oils } & \multicolumn{8}{|c|}{ Minimum inhibitory concentration $(\mu \mathrm{g} / \mathrm{ml})$} & \multirow{2}{*}{$\begin{array}{c}\text { Standard deviation } \\
\text { Ampicillin }\end{array}$} \\
\hline & 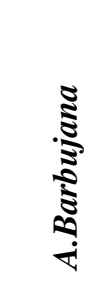 & 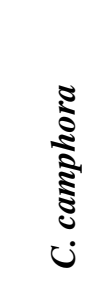 & ن & 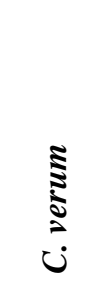 & 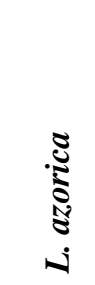 & 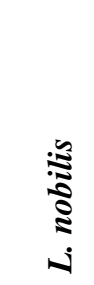 & 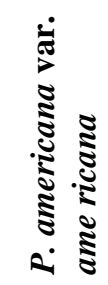 & 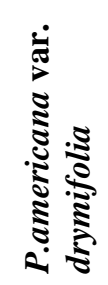 & \\
\hline $\begin{array}{c}\text { Streptococcus pneumoniae } \\
\text { (RCMB 010010) }\end{array}$ & 31.25 & 62.5 & 0.98 & 1.95 & 15.63 & 31.25 & NA & NA & 0.49 \\
\hline $\begin{array}{c}\text { Staphylococcus } \\
\text { aureus(RCMB 010027) }\end{array}$ & 15.63 & 31.25 & 0.49 & 0.98 & 3.9 & 15.63 & NA & NA & 0.49 \\
\hline & & & & & & & & & Vancomycine \\
\hline \multirow[t]{2}{*}{$\begin{array}{c}\text { Methicillin-Resistant } \\
\text { Staphylococcus } \\
\text { aureus(MRSA } 2658 \\
\text { RCMB) } \\
\end{array}$} & 31.25 & 125 & 3.9 & 15.63 & 62.5 & 62.5 & NA & NA & 0.98 \\
\hline & & & & & & & & & Gentamicin \\
\hline $\begin{array}{c}\text { Pseudomonas aeruginosa } \\
\text { (RCMB 010043) }\end{array}$ & NA & NA & NA & NA & NA & NA & NA & NA & 1.95 \\
\hline $\begin{array}{c}\text { Escherichia coli (RCMB } \\
010052)\end{array}$ & 15.63 & 62.5 & 0.98 & 1.95 & 7.81 & 15.63 & 62.5 & 62.5 & 0.98 \\
\hline $\begin{array}{l}\text { Klebsiella pneumoniae } \\
\text { (RCMB } 0010093(12)\end{array}$ & 3.9 & 31.25 & 0.49 & 0.98 & 1.95 & 1.95 & 31.25 & 31.25 & 0.49 \\
\hline
\end{tabular}

*RCMB: Regional center for Mycology and Biotechnology Antimicrobial unit test organism. * NA: no activity. 


\section{Al-Safa H. Mohamed, Wafaa Ahmed, Einas El Shatoury, Magdy M. Mourad}

\section{References}

Abdelwahab SI, Zaman FQ, Mariod AA, Yaacob M, Abdelmageed A, Hassan A, Khamis S (2010) Chemical composition, antioxidant and antibacterial properties of the essential oils of Etlingera elatior and Cinnamomum pubescens Kochummen. J Sci Food Agric 90: 2682-2688

Adams RP (2007) Identification of essential oil components by gas chromatography/massspectrometry, 4th ed. Allured Publishing Corporation, Carol Stream, Illinois

Anwar F, Ali M, Hussain AI, Shahid M (2009) Antioxidant and antimicrobial activities of essential oil and extracts of fennel (Foeniculum vulgare Mill.) seeds from Pakistan. Flavour Fragr $\mathbf{J}$ 24: $170-176$

Baas P, Gregory M (1985) A survey of oil cells in the dicotyledons with comments on their replacement by and joint occurrence with mucilage cells. Isr J Bot 34: 167-186

Bailey LH (1949) Manual of cultivated plants most commonly grown in the continental United States and Canada. Macmillan

Baratta MT, Dorman HJ, Deans SG, Figueiredo AC, Barroso JG, Ruberto G (1998) Antimicrobial and antioxidant properties of some commercial essential oils. Flavour Fragr J 13: 235-244

Boadi NO, Saah SA, Mensah JK, Badu M, Addai-Arhinand S, Mensah MB (2015) Phytoconstituents, antimicrobial and antioxidant properties of the leaves of Persea americana Mill cultivated in Ghana. J Med Plants Res 9: 933-939

Brophy JJ, Goldsack RJ, Forster PI (2001) The leaf oils of the Australian species of Cinnamomum (Lauraceae). J Essent Oil Res 13: 332-335

Burt S (2004) Essential oils: their antibacterial properties and potential applications in foods-a review. Int $\mathbf{J}$ Food Microbiol 94: 223-253

Ceolin GB, Rosito JM, Canto-Dorow TS do (2009) Leaf surface characters applied to Lauraceae taxonomy in a Seasonal Forest of Southern Brazil. Brazilian Arch Biol Technol 52: 14531460

Christenhusz MJM, Byng JW (2016) The number of known plants species in the world and its annual increase. Phytotaxa 261: 201-217

Chu QG, Hu ZH (1999) Comparative anatomy of oil cells and mucilage cells in the leaves of the Lauraceae in China. Acta phytotax $\sin 37$ : $529-540$

Cosoveanu A, Beatrice I, Cabrera R, Nuñez-Trujillo G, González-Coloma A (2013) New antibacterial horizons: study in vitro of plant extracts with bioactivity. J Hortic For Biotechnol 17: 88-94

Derwich E, Benziane Z, Boukir A (2009) Chemical composition and antibacterial activity of leaves essential oil of Laurus nobilis from Morocco. Aust J Basic Appl Sci 3: 3818-3824

Elharas K, Daagare A, Mesifioui A, Ouhssine M (2013) Activité antibactérienne de l'huile essentielle des inflorescences de Laurus Nobilis et Lavandula Angustifolia. Afrique Sci Rev Int des Sci Technol 9: 134-141

Esma Gündüz K, Özbilge H, Albayrak S (2009) Determination of the effect of gentamicin against Staphylococcus aureus by using microbroth kinetic system. Ankem Derg 23: 110-114

Faggetter CD (1987) Leaf cuticles (phytoglyphs) of selected Lauraceae. Anat Dicotyledons Magnoliales, Illiciales, Laurales (Metcalfe, CR ed) 2: $157-160$

Fahn A (1988) Secretory tissues in vascular plants. New Phytol 108: 229-257

Geng S, Cui Z, Huang X, Chen Y, Xu D, Xiong P (2011) Variations in essential oil yield and composition during Cinnamomum cassia bark growth. Ind Crops Prod 33: 248-252

Gottlieb OR, Magalhães MT (1960) Essential oil of the bark and wood of Aniba canellila. Perfum Essent oil Rec 51: $69-70$

Goudjil MB, Ladjel S, Bencheikh SE, Zighmi S, Hamada D (2015) Study of 


\section{Al-Safa H. Mohamed, Wafaa Ahmed, Einas El Shatoury, Magdy M. Mourad}

the chemical composition, antibacterial and antioxidant activities of the essential oil extracted from the leaves of Algerian Laurus nobilis Lauraceae. J Chem Pharm Res 7: 379-385

GuiBoJ, Shi C, RenSen Z (2008) Identification and fungitoxicity of volatiles of invasive plant Wedelia trilobata L. Zhongguo Shengtai Nongye Xuebao/Chinese J EcoAgriculture 16: 905-908

Gustafson JE, Liew YC, Chew S, Markham J, Bell HC, Wyllie SG, Warmington JR (1998) Effects of tea tree oil on Escherichia coli. Lett Appl Microbiol 26: 194-198

Hiroyuki Moteki HH, Yamada Y, Hirotakakat Suzaki KI, Komiya T (2002) Specific induction of apoptosis by 1,8 -cineole in two human leukemia cell lines, but not a in human stomach cancer cell line. Oncol Rep 9: 757-760

Hussain AI, Anwar F, Sherazi STH, Przybylski R (2008) Chemical composition, antioxidant and antimicrobial activities of basil (Ocimum basilicum) essential oils depends on seasonal variations. Food Chem 108: 986-995

Hussin KH, Cutler DF, Moore DM (1992) Leaf anatomical studies of Eugenia L.(Myrtaceae) species from the Malay Peninsula. Bot J Linn Soc 110: 137156

Jantan I bin, Goh SH (1992) Essential oils of Cinnamomum species from Peninsular Malaysia. J Essent Oil Res 4: 161-171

Jantan I bin, Yalvema MF, Ayop N, Ahmad AS (2005) Constituents of the essential oils of Cinnamomum sintoc Blume from a mountain forest of peninsular Malaysia. Flavour Fragr J 20: 601-604

Jantan I, Goh SH (1990) The essential oils of Cinnamomum mollissimum as natural sources of safrole and benzyl benzoate. J Trop For Sci 252-259

Jantan I, Ling YE, Romli S, Ayop N, Ahmad AS (2003) A comparative study of the constituents of the essential oils of three Cinnamomum species from Malaysia. J Essent Oil Res 15: 387-391

Johansen DA (1940) Plant microtechnique. Plant Microtech.

Kamel EA, Loutfy MHA (2001) The significance of cuticular features, petiole anatomy and SDS-PAGE in the Taxonomy of the Lauraceae. J Biol Sci 4: 1094-1100

Koheil MA (2000) Study of the essential oil of the flower-heads of Wedelia trilobata (L) Hitch. J Pharm Sci 26: 288-293

Kordali S, Kotan R, Mavi A, Cakir A, Ala A, Yildirim A (2005) Determination of the chemical composition and antioxidant activity of the essential oil of Artemisia dracunculus and of the antifungal and antibacterial activities of Turkish Artemisia absinthium, A. dracunculus, Artemisia santonicum, and Artemisia spicig. J Agric Food Chem 53: 9452-9458

Kostermans AJGH (1957) Lauraceae. Reinwardtia 4: 193-256

Lawless J (2013) The Encyclopedia of essential oils: the complete guide to the use of aromatic oils in aromatherapy, herbalism, health, and well being. Conari Press

Mann CM, Cox SD, Markham JL (2000) The outer membrane of Pseudomonas aeruginosa NCTC 6749 contributes to its tolerance to the essential oil of Melaleuca alternifolia (tea tree oil). Lett Appl Microbiol 30: 294-297

Marotti M, Piccaglia R, Giovanelli E, Deans SG, Eaglesham E (1994) Effects of variety and ontogenic stage on the essential oil composition and biological activity of fennel (Foeniculum vulgare Mill.). J Essent Oil Res 6: 57-62

Metcalfe CR, Chalk L (1983) Anatomy of the Dicotyledons. Wood structure and conclusion of the general introduction. Vol. II.

Metcalfe CR, Chalk L (1979) Anatomy of the dicotyledons. v. 1: Systematic anatomy of leaf and stem; with a brief history of the subject. v. 2: Wood structure and conclusion of the general 
Al-Safa H. Mohamed, Wafaa Ahmed, Einas El Shatoury, Magdy M. Mourad

introduction.

Metcalfe CR, Chalk L (1950) Anatomy of the dicotyledons, Vols. 1 \& 2. Anat. dicotyledons, Vols. 12

Milhau G, Valentin A, Benoit F, Mallié M, Bastide J-M, Pélissier Y, Bessière JM (1997) In vitro antimalarial activity of eight essential oils. J Essent Oil Res 9: $329-333$

Milos M, Radonic A, Bezic N, Dunkic V (2001) Localities and seasonal variations in the chemical composition of essential oils of Satureja montana L. and S. cuneifolia Ten. Flavour Fragr J 16: $157-160$

Moraes PLR de, Paoli AAS (1999) Epiderme epadrão de venação foliar de espécies de Lauraceae. Acta Bot Brasilica 13: 87-97

Morais A (1972) Oleos essenciais de especies do genero Aniba. Acta Amaz 2: 41-44

Nirmal SA, Chavan MJ, Tambe VD, Jadhav RS, Ghogare PB, Bhalke RD, Girme AS (2005) Chemical composition and antimicrobial activity of essential oil of Wedelia trilobata leaves. Indian J Nat Prod 21: 33-35

Palazzo MC, Agius BR, Wright BS, Haber WA, Moriarity DM, Setzer WN (2009) Chemical compositions and cytotoxic activities of leaf essential oils of four Lauraceae tree species from Monteverde, Costa Rica. Rec Nat Prod 3: $32-37$

Qinggang C, Zhenghai H (1998) Studies on the distribution and structure of oil cells in Litsea tsinlingensis. Acta Bot Boreali-Occidentalia Sin 3: 356-360

Rana VS, Devi CB, Verdeguer M, Blázquez MA (2009) Variation of Terpenoids Constituents in Natural Population of Cinnamomum tamala (L.) Leaves. J Essent Oil Res 21: 531534

Rendle AB (1952) The Classification of Flowering Plants. Vol. II. Cambridge, Engl.

Rohlf FJ (1990) Numerical taxonomy and multivariate analysis system (NTSYSpc). Dep. Ecol. Evol. New York

Rudall P (1994) Anatomy and systematics of
Iridaceae. Bot J Linn Soc 114: 1-21

Santos FA, Rao VSN (2000) Antiinflammatory and antinociceptive effects of 1, 8-cineole a terpenoid oxide present in many plant essential oils. Phyther Res 14: 240-244

Setzer WN, Stokes SL, Penton AF, Takaku S, Haber WA, Hansell E, Caffrey CR, McKerrow JH (2007) Cruzain inhibitory activity of leaf essential oils of Neotropical Lauraceae and essential oil components. Actividad inhibidora de la cruzain de los aceites esenciales de la hoja de lauráceas neotropicales y componentes del aceite esencial. Nat Prod Commun 2: 1203-1210

Short MI (1994) Lauraceae: In: I. R. PRESS \& M. I. Short (ed.), Flora of Madeira. London, pp: 100-102.

Sikkema J, De Bont JAM, Poolman B (1994) Interactions of cyclic hydrocarbons with biological membranes. J Biol Chem 269:

Singh C, Singh S, Pande C, Tewari G, Pande V, Sharma P (2013) Exploration of antimicrobial potential of essential oils of Cinnamomum glanduliferum, Feronia elephantum, Bupleurum hamiltonii and Cyclospermum leptophyllum against foodborne pathogens. Pharm Biol 51: 1607-1610

Sivropoulou A, Nikolaou C, Papanikolaou E, Kokkini S, Lanaras T, Arsenakis M (1997) Antimicrobial, cytotoxic, and antiviral activities of Salvia fructicosa essential oil. J Agric Food Chem 45: 3197-3201

Su J, Chen J, Liao S, Li L, Zhu L, Chen L (2012) Composition and biological activities of the essential oil extracted from a novel plant of Cinnamomum camphora Chvar. Borneol. J Med Plants Res 6: 3487-3494

Takaku S, Haber WA, Setzer WN (2007) Leaf essential oil composition of 10 species of Ocotea (Lauraceae) from Monteverde, Costa Rica. Biochem Syst Ecol 35: 525-532

Trajano VN, Lima E de O, Travassos AE, Souza EL de (2010) Inhibitory effect 
Al-Safa H. Mohamed, Wafaa Ahmed, Einas El Shatoury, Magdy M. Mourad

of the essential oil from Cinnamomum zeylanicum Blume leaves on some food-related bacteria. Food Sci Technol 30: 771-775

Watson L, Dallwitz MJ (1992) The families of flowering plants: descriptions, illustrations, identification, and information retrieval. Version: 14th December 2000. biodiversity. uno. edu/delta 


\section{Al-Safa H. Mohamed, Wafaa Ahmed, Einas El Shatoury, Magdy M. Mourad}

\section{Appendix}

Chemical composition of the essential oils of the studied taxa of Lauraceae

\begin{tabular}{|c|c|c|c|c|c|c|c|c|c|}
\hline Compound & Rt & 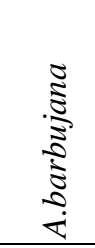 & 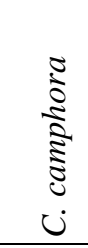 & 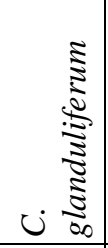 & 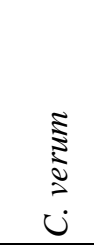 & 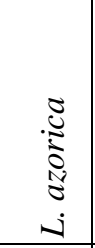 & 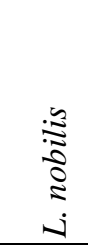 & 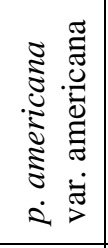 & 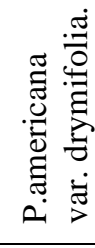 \\
\hline 1. Ethane, 1,1-diethoxy- & 3.029 & - & - & - & - & - & 0.10 & - & - \\
\hline $\begin{array}{l}\text { 2. Acetic acid, 4,5-diacetoxy-6-acetoxymethyl-2- } \\
\text { (3-formylindol-1-yl)-tetrahydropyran-3-yl ester. }\end{array}$ & 3.035 & - & - & - & - & - & - & - & 0.52 \\
\hline 3. Butanal, 3-(1-ethoxyethoxy)-2-methyl- & 3.036 & 0.37 & 0.27 & 0.45 & 0.41 & 0.37 & - & 0.10 & - \\
\hline 4. Cyclopentane, ethyl- & 3.070 & 2.38 & 1.83 & 3.18 & 2.92 & 2.63 & 0.74 & 0.75 & 4.00 \\
\hline $\begin{array}{l}\text { 5. Cyclopentane, 1,2,3-trimethyl-, } \\
\text { (1.alpha.,2.alpha.,3.alpha.)- }\end{array}$ & 3.144 & 0.24 & - & 0.36 & - & 0.27 & 0.07 & 0.04 & 0.36 \\
\hline 6. Octacosyltrifluoroacetate. & 3.152 & - & 0.18 & - & - & - & - & - & - \\
\hline $\begin{array}{l}\text { 7. Spirosolan-3-ol, 28-acetyl-, acetate (ester), } \\
\text { (3.beta.,5.alpha.,22.beta.,25S)- }\end{array}$ & 3.152 & - & - & - & 0.28 & - & - & - & - \\
\hline 8. Rubratoxin B triacetate. & 3.195 & - & - & 0.13 & - & -- & - & - & - \\
\hline $\begin{array}{l}\text { 9. Cholestan-3-amine, N,N,4,4-tetramethyl-, } \\
\text { (3.beta.,5.alpha.)- }\end{array}$ & 3.272 & - & - & - & 0.28 & - & - & - & - \\
\hline $\begin{array}{l}\text { 10.9-Hexadecenoic acid, 9-hexadecenyl ester, } \\
(\mathrm{Z}, \mathrm{Z}) \text { - }\end{array}$ & 3.273 & - & - & - & - & - & - & - & 0.34 \\
\hline 11. Octatriacontane, 3,5-dimethyl- & 3.274 & 0.23 & - & - & - & - & - & - & - \\
\hline 12. Heneicosyltrifluoroacetate. & 3.274 & - & - & 0.27 & - & - & - & - & - \\
\hline 13. Cyclooctacosane. & 3.275 & - & - & - & - & 0.17 & - & - & - \\
\hline 14. Norbornane. & 3.364 & 0.90 & 0.57 & 1.15 & 1.04 & 0.91 & 0.23 & 0.25 & 1.41 \\
\hline 15. Propanoic acid, 2-methyl-, ethyl ester. & 3.480 & - & 0.39 & - & - & 0.66 & 0.16 & - & - \\
\hline $\begin{array}{l}\text { 16. Tris(3-(p-nitrophenyl)-2,4- } \\
\text { pentanedionato)iron(iii). }\end{array}$ & 3.487 & - & - & - & - & - & - & 0.19 & - \\
\hline 17. Propanoic acid, 2-methyl-, ethyl ester. & 3.487 & - & - & - & - & - & - & - & 0.98 \\
\hline
\end{tabular}


Al-Safa H. Mohamed, Wafaa Ahmed, Einas El Shatoury, Magdy M. Mourad

\begin{tabular}{|c|c|c|c|c|c|c|c|c|c|}
\hline $\begin{array}{l}\text { 18. 1-Nitro-1-deoxy-d-manno-1-gluco-octitol, } \\
\text { heptaacetate. }\end{array}$ & 3.489 & 0.65 & - & - & - & - & - & - & - \\
\hline $\begin{array}{l}\text { 19. } 5(4 \mathrm{H}) \text {-Oxazolone, } 4,4^{\prime}-(1,4- \\
\text { phenylenedimethylidyne }) \text { bis[2-phenyl- }\end{array}$ & 3.489 & - & - & 0.90 & - & - & - & - & - \\
\hline 20. 1-Bromodocosane. & 3.489 & - & - & - & 0.61 & - & - & - & - \\
\hline $\begin{array}{l}\text { 21. 1'-Acetyl-1-butyryl-1,1',2,2',3,4-hexahydro- } \\
\text { 2,2,2',2',4,4'-hexamethyl-4,6'-biquinolyl. }\end{array}$ & 3.545 & - & - & - & - & - & - & - & 0.45 \\
\hline 22. Tritriacontane. & 3.546 & - & 0.20 & - & - & - & - & - & - \\
\hline 23. Diethylmalonic acid, dodecyl tetradecyl ester. & 3.546 & - & - & - & - & - & - & 0.10 & - \\
\hline 24. Heneicosylpentafluoropropionate. & 3.547 & 0.31 & - & - & - & - & - & - & - \\
\hline 25. Heptane, 2-methyl- & 3.547 & - & - & - & - & - & - & - & - \\
\hline 26. Dotriacontylheptafluorobutyrate. & 3.547 & - & - & 0.51 & - & - & - & - & - \\
\hline 27. Hentriacontane. & 3.547 & - & - & - & 0.33 & - & - & - & - \\
\hline $\begin{array}{l}\text { 28. 1-Deoxy-1-piperidinocarbothioamido-.beta.-d- } \\
\text { glucopyranose 2,3,4,6-tetraacetate. }\end{array}$ & 3.580 & 0.11 & - & - & - & - & - & - & - \\
\hline 29. Toluene. & 3.613 & 2.99 & 2.37 & 4.13 & 3.66 & 3.39 & 0.94 & 0.92 & 4.96 \\
\hline 30. Pentatriacontane, 1-bromo- & 3.687 & - & - & - & - & - & - & - & 0.26 \\
\hline $\begin{array}{l}\text { 31.4-Acetoxy-2-benzyloxy-3,3-dimethyl-4-[2- } \\
\text { pyrimidinylamino]sulfonyl]butyranilide. }\end{array}$ & 3.689 & 0.19 & - & - & - & - & - & - & - \\
\hline $\begin{array}{l}\text { 32. alpha.-[2-Piperidyl]-2,6-di-[p- } \\
\text { trifluoromethylphenyl]-4-pyridinemethanol. }\end{array}$ & 3.689 & - & - & 0.25 & - & - & - & - & - \\
\hline 33. Pentatriacontane. & 3.689 & - & - & - & 0.23 & - & - & - & - \\
\hline $\begin{array}{l}\text { 34. Phenanthrene-10-ethanamine, 3-bromo-.beta.- } \\
\text { hydroxy-N,N-diheptyl-, hydrosulfate. }\end{array}$ & 3.690 & - & 0.12 & - & - & - & - & - & - \\
\hline 35. Triacontane, 1-bromo- & 3.691 & - & - & - & - & 0.16 & 0.16 & - & - \\
\hline 36. Acetic acid, butyl ester (Isobutyl acetate). & 3.734 & - & 3.62 & 6.21 & 5.65 & 4.93 & 1.40 & - & 7.53 \\
\hline $\begin{array}{l}\text { 37.14-Oxa-1,11- } \\
\text { diazatetracyclo[7.4.1.0(2,7).0(10,12)]tetradeca- } \\
\text { 2,4,6-triene, 11-acetyl-6,9-bis(acetyloxy)-4-formy. }\end{array}$ & 3.743 & - & - & - & - & - & - & 1.43 & - \\
\hline 38. Heptadecafluorononanoic acid, butyl ester. & 3.744 & 4.63 & - & - & - & - & - & - & - \\
\hline 39. Cyclohexane, 1,3-dimethyl-, cis- & 3.794 & 0.31 & 0.26 & 0.42 & 0.38 & 0.30 & 0.10 & - & - \\
\hline $\begin{array}{l}\text { 40. 2-[3,4-Dichlorophenyl]-4-[[1-ethyl-3- } \\
\text { piperidyl]amino]-6-[trichloromethy]-S-trazine. }\end{array}$ & 3.802 & - & - & - & - & - & - & - & 0.50 \\
\hline
\end{tabular}


Al-Safa H. Mohamed, Wafaa Ahmed, Einas El Shatoury, Magdy M. Mourad

\begin{tabular}{|c|c|c|c|c|c|c|c|c|c|}
\hline 41. Octacosyltrifluoroacetate. & 3.805 & - & - & - & - & - & - & 0.11 & - \\
\hline 42. Urs-12-en-3-ol, acetate, (3.beta.)- & 3.830 & - & - & - & - & - & - & - & 0.18 \\
\hline $\begin{array}{l}\text { 43. Benzeneacetylamine, N-benzyl-4-benzyloxy- } \\
\text { N-t-butyl-3-vinyloxy- }\end{array}$ & 3.840 & 0.11 & - & - & - & - & - & - & - \\
\hline $\begin{array}{l}\text { 44. Nickel, bis[N,N'-1,2- } \\
\text { ethanediylidenebis[cyclohexanamine]-N,N']-, (t- } \\
\text { 4)- }\end{array}$ & 3.840 & - & - & - & - & 0.12 & - & - & - \\
\hline $\begin{array}{l}\text { 45. Hydroxy-bis(4-trifluoromethyl-phenyl)acetic } \\
\text { acid, 1-methylpiperidin-4-yl ester. }\end{array}$ & 3.840 & - & - & - & 0.14 & - & - & - & - \\
\hline 46. Dichloroacetic acid, 1-cyclopentylethyl ester. & 3.845 & - & - & 0.14 & - & - & - & - & - \\
\hline $\begin{array}{l}\text { 47. 1-Deoxy-1-[3-(2-methoxyphenyl)-2- } \\
\text { thioureido]-.beta.-d-glucopyranose 2,3,4,6- } \\
\text { tetraacetate. }\end{array}$ & 4.055 & - & 0.16 & - & - & - & - & - & - \\
\hline 48. Dotriacontane. & 4.209 & - & - & - & - & - & - & - & 0.32 \\
\hline 49. Heptane, 2,4-dimethyl- & 4.211 & 0.44 & 0.24 & - & - & 0.14 & - & - & - \\
\hline $\begin{array}{l}\text { 50. 2,6,10,14-tetramethylpentadecanoic acid, } \\
2,2,3,3,4,4,4 \text {-heptafluorobutyl ester. }\end{array}$ & 4.213 & - & - & 0.30 & - & - & - & - & - \\
\hline 51. Hexane, 2,4-dimethyl- & 4.213 & - & - & - & 0.30 & - & - & - & - \\
\hline $\begin{array}{l}\text { 52. 2-Butenoic acid, 2-methyl-, 2-(acetyloxy)- } \\
\text { 1,1a,2,3,4,6,7,10,11,11a-decahydro-7,10- } \\
\text { dihydroxy-1,1,3,6,9- }\end{array}$ & 4.252 & 0.48 & - & - & - & - & - & - & - \\
\hline $\begin{array}{l}\text { 53. Spiro(1,3-dioxolane)-2,3'-pregn-5'-en-20'-ol, } \\
11 \text { '-acetoxy-18'-(methylamino)- }\end{array}$ & 4.252 & - & - & - & - & - & - & - & 0.47 \\
\hline 54. Acetic acid, butyl ester (Butyl acetate). & 4.559 & 16.20 & 12.76 & 21.96 & 20.12 & $\begin{array}{c}17.9 \\
1 \\
\end{array}$ & 4.98 & 5.01 & 26.31 \\
\hline 55. Decanoic acid, 10,10'-diselenodi- & 4.697 & - & 0.17 & - & - & - & - & - & - \\
\hline $\begin{array}{l}\text { 56. Thiophene-2-carboxylic acid, } 3-(2- \\
\text { isobutyrylhydrazino)-4-(propane-1-sulfonyl)-, } \\
\text { methyl ester. }\end{array}$ & 4.705 & - & - & 0.13 & - & - & - & - & - \\
\hline 57. Cyclohexane, ethyl- & 4.997 & - & - & - & - & - & - & - & 0.15 \\
\hline 58. 2-Hexenal, (E)- & 5.511 & - & - & - & - & - & - & 0.22 & - \\
\hline 59. Butanoic acid, 3-methyl-, ethyl ester. & 5.517 & - & 0.15 & 0.33 & 0.37 & 0.32 & 0.08 & - & 0.65 \\
\hline 60. Pentanoic acid, octyl ester. & 5.523 & 0.35 & - & - & - & - & - & - & - \\
\hline
\end{tabular}


Al-Safa H. Mohamed, Wafaa Ahmed, Einas El Shatoury, Magdy M. Mourad

\begin{tabular}{|c|c|c|c|c|c|c|c|c|c|}
\hline $\begin{array}{l}\text { 61.Cyclopenta[d]anthracene, 3-isopropyl-8,11- } \\
\text { bis(benzyloxy)-6(6aH)-oxo-1,2,3,3a,4,5,7,12- } \\
\text { octahydro- }\end{array}$ & 5.915 & 0.13 & - & - & - & - & - & - & - \\
\hline 62. Benzene, 1,3-dimethyl- & 5.918 & - & - & - & - & - & - & - & 0.16 \\
\hline $\begin{array}{l}\text { 63. 1-Butanol, 3-methyl-, acetate (Isoamyl } \\
\text { acetate). }\end{array}$ & 6.126 & 1.44 & 1.14 & 1.90 & 1.75 & - & 0.45 & 0.46 & 2.31 \\
\hline $\begin{array}{l}\text { 64. 3,6-Di-trifluoromethyl-9-[1-hydroxy-3-[N-n- } \\
\text { butylamino]propyl]phenanthrene. }\end{array}$ & 6.139 & - & - & - & - & 1.58 & - & - & - \\
\hline 65. Pseduotomatidin-5,20-dien diacetate. & 6.214 & - & 0.16 & - & - & - & - & - & - \\
\hline $\begin{array}{l}\text { 66. Acetic acid, 2,6-dibromo-4-(4- } \\
\text { morpholinylthiocarbonyl)phenyl ester. }\end{array}$ & 6.214 & - & - & 0.28 & - & - & - & - & - \\
\hline $\begin{array}{l}\text { 67. 11,18-Diacetoxy-5,6,12,17- } \\
\text { trinaphthylenetetrone. }\end{array}$ & 6.215 & - & - & - & - & - & - & - & 0.20 \\
\hline $\begin{array}{l}\text { 68. Benzophenone, 5-chloro-2-[[N- } \\
\text { [diacetyloxy]acetyl]methylamino]- }\end{array}$ & 6.218 & - & - & - & 0.15 & - & - & - & - \\
\hline $\begin{array}{l}\text { 69. 8-Bromo-6-(2-chlorophenyl)-1-[4-(2- } \\
\text { phenoxyethyl)-1-piperazinyl]-4H-1,2,4- } \\
\text { triazolo[4,3-a]thieno[3,2-f]- }\end{array}$ & 6.305 & - & 0.10 & - & - & - & - & - & - \\
\hline $\begin{array}{l}\text { 70. Hydroxy-bis(4-trifluoromethyl-phenyl)acetic } \\
\text { acid, 1-methylpiperidin-4-yl ester. }\end{array}$ & 6.379 & - & - & - & - & - & - & - & 0.17 \\
\hline 71. o-Xylene. & 6.552 & - & - & - & - & 0.24 & 0.05 & - & - \\
\hline $\begin{array}{l}\text { 72. N-Acetyl tri-O-benzyl-1-O-benzoyl-.beta.-d- } \\
\text { galactosamine. }\end{array}$ & 6.564 & - & - & 0.29 & - & - & - & - & - \\
\hline $\begin{array}{l}\text { 73. 9-.alpha.-[2,3,5-O-Tribenzyl-d- } \\
\text { arabinosyl]adenine. }\end{array}$ & 6.564 & - & - & - & - & - & - & - & 0.39 \\
\hline $\begin{array}{l}\text { 74. psi.,.psi.-Carotene, 3,4-didehydro-1,2-dihydro- } \\
\text { 1-methoxy- }\end{array}$ & 6.566 & - & 0.15 & - & - & - & - & - & - \\
\hline $\begin{array}{l}\text { 75. Galactose, 2-acetamido-2-deoxy-1,3,4,6- } \\
\text { tetrabenzyl- }\end{array}$ & 6.568 & 0.20 & - & - & - & - & - & - & - \\
\hline $\begin{array}{l}\text { 76. }(2 \mathrm{R}, 3 \mathrm{R})-(-)-2-B e n z y l o x y-1,3,4 \text {-butanetriol, } \\
\text { tris(trifluoroacetate). }\end{array}$ & 6.568 & - & - & - & 0.25 & - & - & - & - \\
\hline 77.Heptacosane, 1-chloro- & 6.718 & - & - & - & - & - & - & - & 0.26 \\
\hline 78. Dotriacontane. & 6.723 & - & 0.17 & - & - & - & - & - & - \\
\hline
\end{tabular}


Al-Safa H. Mohamed, Wafaa Ahmed, Einas El Shatoury, Magdy M. Mourad

\begin{tabular}{|c|c|c|c|c|c|c|c|c|c|}
\hline $\begin{array}{l}\text { 79. 6-Hydroxy-7-nonadecylmercapto-5,8- } \\
\text { quinolindione. }\end{array}$ & 6.723 & - & - & - & 0.20 & - & - & - & - \\
\hline 80. Pentatriacontane. & 6.724 & - & - & 0.14 & - & - & - & - & - \\
\hline 81. Hentriacontane. & 6.725 & 0.14 & - & - & - & - & - & - & - \\
\hline 82. 3-Hexanol, 5-methyl- & 7.028 & - & 0.20 & - & - & - & - & - & - \\
\hline 83. 2-Pentanol, 2-methyl- & 7.030 & 0.27 & - & 0.40 & 0.28 & 0.31 & - & 0.09 & 0.37 \\
\hline $\begin{array}{l}\text { 84. Leucine, N-[N-[N-(N-stearoyl-L-alanyl)-L- } \\
\text { valyl]glycyl]-, methyl ester, L- }\end{array}$ & 7.517 & - & - & - & - & - & - & - & 0.20 \\
\hline $\begin{array}{l}\text { 85. Bicyclo[3.1.0]hex-2-ene, 2-methyl-5-(1- } \\
\text { methylethyl)- (alpha-Thujene). }\end{array}$ & 7.525 & - & - & 0.64 & 1.19 & - & 0.26 & - & - \\
\hline $\begin{array}{l}\text { 86. 1,3-Dimethyl-7-propyl-8-[(1-deoxy-2,3:4,5-di- } \\
\text { O-isopropylidenexylitol-1-ylimino)methyl]-3,7- } \\
\text { dihydro-purine- }\end{array}$ & 7.523 & 0.19 & - & - & - & - & - & - & - \\
\hline $\begin{array}{l}\text { 87. N-(6-Benzyl-3-cyano-4,5,6,7-tetrahydro- } \\
\text { thieno[2,3-c]pyridin-2-yl)-2,3,3,3-tetrafluoro-2- } \\
\text { methoxy-propionamid. }\end{array}$ & 7.538 & - & 0.27 & - & - & - & - & - & - \\
\hline $\begin{array}{l}\text { 88. psi.,.psi.-Carotene, 3,4-didehydro-1,1',2,2'- } \\
\text { tetrahydro-1'-hydroxy-1-methoxy- }\end{array}$ & 7.539 & - & - & - & - & 0.45 & - & - & - \\
\hline $\begin{array}{l}\text { 89. (1R)-2,6,6-Trimethylbicyclo[3.1.1]hept-2-ene } \\
\text { ( alpha-Pinene). }\end{array}$ & 7.726 & 0.76 & 3.23 & 3.58 & 2.45 & 2.65 & 1.18 & 1.75 & 0.90 \\
\hline $\begin{array}{l}\text { 90. Bicyclo[2.2.1]heptane, 2,2-dimethyl-3- } \\
\text { methylene-, (1S)- (Camphene). }\end{array}$ & 8.177 & - & 2.46 & - & - & - & 0.08 & - & - \\
\hline 91. Pseudosolasodinediacetate. & 8.191 & - & - & - & - & 0.28 & - & - & - \\
\hline 92. 9-Methyltritriacontane. & 8.825 & - & - & - & - & 0.18 & - & - & - \\
\hline $\begin{array}{l}\text { 93. 2-Butenoic acid, 2-methyl-, 2-(acetyloxy)- } \\
\text { 1,1a,2,3,4,6,7,10,11,11a-decahydro-7,10- } \\
\text { dihydroxy-1,1,3,6,9- }\end{array}$ & 8.828 & - & 0.14 & - & - & - & - & - & - \\
\hline 94. Tetracosane, 12-decyl-12-nonyl- & 8.829 & - & - & - & - & - & - & - & 0.37 \\
\hline 95. Cyclopentanol, 1-methyl- & 8.833 & 0.16 & - & - & - & - & - & - & - \\
\hline 96. Tetracosane, 12-decyl-12-nonyl- & 8.834 & - & - & 0.31 & - & - & - & - & - \\
\hline 97. .beta.-Phellandrene. & 8.944 & - & - & 15.06 & 2.72 & 3.72 & 2.97 & - & 0.90 \\
\hline 98. Rhodium 1,5-cyclooctadiene chloride dimer. & 8.960 & - & - & - & - & - & - & 0.10 & - \\
\hline 99. Picolinyl 9,12,15,18-tetracosatetraenoate. & 8.964 & - & 0.14 & - & - & - & - & - & - \\
\hline
\end{tabular}


Al-Safa H. Mohamed, Wafaa Ahmed, Einas El Shatoury, Magdy M. Mourad

\begin{tabular}{|c|c|c|c|c|c|c|c|c|c|}
\hline $\begin{array}{l}\text { 100.Bicyclo[3.1.1]heptane, 6,6-dimethyl-2- } \\
\text { methylene-, (1S)- (beta-Pinene). }\end{array}$ & 9.037 & 0.27 & 1.28 & 3.53 & 1.06 & 2.03 & 1.22 & 2.60 & 1.34 \\
\hline 101. beta.-Myrcene (Myrcene). & 9.487 & 1.67 & 1.40 & 1.11 & 1.69 & 0.52 & 0.41 & 0.30 & - \\
\hline $\begin{array}{l}\text { 102. 2-Propenoic acid, 2-methyl-, (1- } \\
\text { methylethylidene)di-4,1-phenylene ester. }\end{array}$ & 9.492 & - & - & - & - & - & - & - & 0.16 \\
\hline $\begin{array}{l}\text { 103. Cobalt, nonacarbonyl[.mu.3- } \\
\text { (oxophenylethylidyne)]tri-, triangulo. }\end{array}$ & 9.575 & - & - & 0.11 & - & - & - & - & - \\
\hline 104. 2-Chloro-2,4-dimethylpentane. & 9.595 & - & - & - & 0.12 & - & - & - & - \\
\hline 105. alpha.-Phellandrene. & 9.904 & 31.01 & - & - & 13.06 & - & - & - & - \\
\hline $\begin{array}{l}\text { 106. N-Carbobenzyloxy-l-aspartic acid, dibenzyl } \\
\text { ester. }\end{array}$ & 9.904 & - & - & 0.29 & - & - & - & - & - \\
\hline $\begin{array}{l}\text { 107. 2-(5-Chloro-3-trifluoromethyl-pyridin-2- } \\
\text { ylamino)-3,3,3-trifluoro-2-(2-methyl- } \\
\text { benzoylamino)-propionic. }\end{array}$ & 9.908 & - & 0.15 & - & - & - & - & - & - \\
\hline 108. 3-Carene. & 10.082 & - & - & - & 0.69 & 1.56 & 0.24 & - & - \\
\hline 109. (+)-4-Carene (alpha-Terpinene). & 10.279 & - & - & - & - & - & 0.24 & - & - \\
\hline $\begin{array}{l}\text { 110. Indol-3(2H)-one, 5-bromo-4-chloro-2-(2- } \\
\text { methoxybenzylaminomethylene). }\end{array}$ & 10.285 & - & - & - & - & 0.22 & - & - & - \\
\hline $\begin{array}{l}\text { 111. Glutaric acid, hexadecyl 3-methoxybenzyl } \\
\text { ester. }\end{array}$ & 10.292 & - & - & - & 0.42 & - & - & - & - \\
\hline $\begin{array}{l}\text { 112. Benzene, 2,3-dimethyl-1,4-bis(2,6-dimethyl- } \\
\text { 4-methoxyphenylazo)- }\end{array}$ & 10.295 & - & - & 0.56 & - & - & - & - & - \\
\hline 113. o-Cymene (m-Cymene). & 10.455 & - & - & - & - & 0.64 & 0.12 & - & - \\
\hline 114. o-Cymene (p-Cymene). & 10.532 & 4.96 & 0.58 & 0.53 & 2.20 & 0.52 & 0.25 & - & - \\
\hline 115. D-Limonene. & 10.665 & - & 3.79 & - & 1.21 & 1.17 & 1.07 & 0.17 & - \\
\hline $\begin{array}{l}\text { 116. Pregnane-11,20-dione, 3,21- } \\
\text { bis[(trimethylsilyl)oxy]-, 20-[O- } \\
\text { (phenylmethyl)oxime], (3.alpha.,5.beta.)- }\end{array}$ & 10.667 & - & - & - & - & - & - & - & 0.60 \\
\hline 117. Tetrahydrosarsasapogenintribenzoate. & 10.678 & - & - & 1.14 & - & - & - & - & - \\
\hline 118. beta.-Phellandrene. & 10.680 & 2.02 & - & - & - & - & - & - & - \\
\hline 119. Eucalyptol (Cineole). & 10.746 & - & - & 20.49 & 15.27 & $\begin{array}{c}29.3 \\
0\end{array}$ & 29.32 & 0.32 & 2.26 \\
\hline 120. 3-O-Acetyl-6-methoxy-cycloartenol. & 10.778 & - & 0.12 & - & - & - & - & - & - \\
\hline
\end{tabular}


Al-Safa H. Mohamed, Wafaa Ahmed, Einas El Shatoury, Magdy M. Mourad

\begin{tabular}{|c|c|c|c|c|c|c|c|c|c|}
\hline 121. trans-.beta.-Ocimene. & 10.966 & 7.54 & - & - & - & - & - & 0.18 & - \\
\hline $\begin{array}{l}\text { 122. 1,3,6-Octatriene, 3,7-dimethyl-, (Z)-(beta-cis- } \\
\text { Ocimene). }\end{array}$ & 11.281 & 1.87 & - & - & - & - & 0.20 & 0.16 & - \\
\hline 123. Cholestanone oxime acetate. & 11.289 & - & - & - & 0.36 & - & - & - & - \\
\hline 124. .gamma.-Terpinene. & 11.621 & - & - & 0.93 & 0.73 & 0.37 & 0.49 & - & - \\
\hline $\begin{array}{l}\text { 125. Acetic acid, 13-acetoxymethyl-17-acetyl-9- } \\
\text { hydroxy-10-methyl-3-oxo- } \\
2,3,6,7,8,9,10,11,12,13,14,15,16,17 \text {-tetra. }\end{array}$ & 11.631 & - & - & - & - & - & - & - & 0.24 \\
\hline $\begin{array}{l}\text { 126.Bicyclo[3.1.0]hexan-2-ol, 2-methyl-5-(1- } \\
\text { methylethyl)-, (1.alpha.,2.beta.,5.alpha- }\end{array}$ & 11.893 & - & - & - & - & - & 0.20 & - & - \\
\hline 127. N-Methyl-pseudotomatidinediacetate. & 12.495 & - & - & - & 0.16 & - & - & - & - \\
\hline $\begin{array}{l}\text { 128. Rhodium, di-.mu.-chlorobis(.eta.4-1,2- } \\
\text { diethenylcyclohexane)di-, stereoisomer }\end{array}$ & 12.555 & - & - & - & - & - & - & - & 0.25 \\
\hline 129.2-Carene. & 12.564 & - & 0.18 & - & 2.10 & - & 0.18 & - & - \\
\hline $\begin{array}{l}\text { 130. 4H- } \\
\text { Cyclopropa[5',6']benz[1',2':7,8]azuleno[5,6- } \\
\text { b]oxiren-4-one, 8,8a-bis(acetyloxy)-2a- } \\
\text { [(acetyloxy)methyl]- }\end{array}$ & 12.573 & - & - & - & - & 0.15 & - & - & - \\
\hline 131. 2-Nonanone. & 12.678 & - & - & - & - & - & - & 0.11 & - \\
\hline 132. Bonomycin hydrochloride. & 12.700 & - & - & - & - & - & - & - & 0.33 \\
\hline 133. 1,6-Octadien-3-ol, 3,7-dimethyl- (Linalool). & 12.909 & 0.13 & - & - & - & 0.96 & 15.78 & - & 4.11 \\
\hline 134. Docosyltrifluoroacetate. & 13.057 & 0.46 & - & - & - & - & - & - & - \\
\hline 135. Octacosyltrifluoroacetate. & 13.052 & - & - & - & - & - & - & - & 0.21 \\
\hline $\begin{array}{l}\text { 136. 2-Cyclohexen-1-ol, 1-methyl-4-(1- } \\
\text { methylethyl)-, cis- }\end{array}$ & 14.180 & - & - & - & - & - & 0.14 & - & - \\
\hline $\begin{array}{l}\text { 137. Hexadecahydrocyclopenta[a]phenanthren-17- } \\
\text { one, 16-(1-ethyl-1H-pyrazol-4-ylmethylene)- } \\
\text { 10,13-dimethyl- }\end{array}$ & 14.185 & - & - & - & - & 0.10 & - & - & - \\
\hline 138. (+)-2-Bornanone (Camphor). & 14.355 & - & 59.22 & - & 5.14 & - & 15.67 & - & 2.38 \\
\hline 139. L-.alpha.-Terpineol (Myrcenol). & 15.039 & - & - & - & - & 0.23 & 0.38 & - & - \\
\hline 140. Terpinen-4-ol. & 15.359 & - & 0.35 & 1.64 & 1.26 & 2.01 & 2.54 & - & 0.76 \\
\hline 141. alpha.-Terpineol. & 15.765 & - & - & 5.04 & 3.24 & 2.42 & 2.66 & 0.09 & 0.79 \\
\hline 142. Cholestanone oxime acetate. & 15.772 & - & 0.36 & - & - & - & - & - & 0.48 \\
\hline
\end{tabular}


Al-Safa H. Mohamed, Wafaa Ahmed, Einas El Shatoury, Magdy M. Mourad

\begin{tabular}{|c|c|c|c|c|c|c|c|c|c|}
\hline 143. Estragole. & 16.007 & - & - & - & 0.22 & - & - & 81.32 & - \\
\hline $\begin{array}{l}\text { 144. 2,6-Octadien-1-ol, 3,7-dimethyl-, (Z)- (cis- } \\
\text { Geraniol). }\end{array}$ & 16.869 & - & - & - & - & - & 0.17 & - & - \\
\hline 145. Linalyl acetate. & 17.654 & - & - & - & - & - & 0.25 & - & - \\
\hline 146. Cyclooctacosane. & 17.855 & 0.30 & - & - & - & - & - & - & - \\
\hline 147. 4-Thujen-2.alpha.-yl acetate. & 18.279 & - & - & - & - & - & 0.14 & - & - \\
\hline 148. Cyclooctanol, acetate. & 18.303 & - & - & - & - & - & - & 0.17 & - \\
\hline 149. Bornyl acetate. & 18.628 & - & - & - & - & 0.50 & - & - & - \\
\hline $\begin{array}{l}\text { 150. 3-Cyclohexene-1-methanol, alpha.,.alpha.,4- } \\
\text { trimethyl-, acetate. }\end{array}$ & 19.498 & - & - & - & - & 0.69 & 0.44 & - & - \\
\hline $\begin{array}{l}\text { 151. 2-Oxabicyclo[2.2.2] octan-6-ol, 1,3,3- } \\
\text { trimethyl-, acetate. }\end{array}$ & 20.214 & - & - & - & - & - & 0.13 & - & - \\
\hline $\begin{array}{l}\text { 152. } 3 \text {-Cyclohexene-1-methanol, alpha, alpha.,4- } \\
\text { trimethyl-, acetate( } \alpha \text {-terpinyl acetate). }\end{array}$ & 20.407 & 1.08 & - & - & - & 9.61 & 7.11 & - & 13.39 \\
\hline 153. Eugenol. & 20.646 & - & - & - & - & - & 0.62 & - & - \\
\hline 154. 10-Undecenal. & 21.790 & 0.78 & - & - & - & - & - & - & - \\
\hline 155. Methyleugenol. & 21.913 & - & - & - & - & 0.51 & 2.96 & 0.95 & 3.55 \\
\hline $\begin{array}{l}\text { 156. 3-(4-Adamantan-1-yl-piperazin-1-yl)-1-(4- } \\
\text { ethoxy-phenyl)-pyrrolidine-2,5-dione. }\end{array}$ & 21.915 & 0.09 & - & - & - & - & - & - & - \\
\hline 157. Dodecanal. & 21.982 & 0.33 & - & - & - & - & - & - & - \\
\hline 158. Caryophyllene. & 22.423 & 4.96 & 0.36 & - & 1.19 & - & 0.18 & 0.61 & 0.95 \\
\hline $\begin{array}{l}\text { 159. Acetic acid, cinnamyl ester (Cinnamyl } \\
\text { acetate). }\end{array}$ & 22.992 & - & - & - & - & 0.42 & 0.09 & - & - \\
\hline 160. Humulene. & 23.343 & 0.40 & - & - & - & - & - & - & - \\
\hline $\begin{array}{l}\text { 161. Cholan-24-oic acid, 3-(acetyloxy)-12-oxo-, } \\
\text { methyl ester, (3.alpha.,5.beta.)- }\end{array}$ & 23.633 & - & - & - & - & - & - & - & 0.37 \\
\hline $\begin{array}{l}\text { 162. 1,6-Cyclodecadiene, 1-methyl-5-methylene- } \\
\text { 8-(1-methylethyl)-, [S-(E,E)]-(Germacrene D). }\end{array}$ & 24.064 & 1.27 & - & - & 0.26 & 0.38 & - & - & 0.32 \\
\hline 163. Cochlioquinone A. & 24.370 & - & - & - & - & - & - & - & 0.24 \\
\hline $\begin{array}{l}\text { 164. Cyclohexane, 1-ethenyl-1-methyl-2-(1- } \\
\text { methylethenyl)-4-(1-methylethylidene)- } \\
\text { (Germacrene B). }\end{array}$ & 24.474 & - & - & - & 2.60 & - & 0.12 & - & 0.44 \\
\hline 165. Nonanoic acid, 9,9'-diselenodi- & 24.480 & - & - & 0.50 & - & - & - & - & \\
\hline
\end{tabular}


Al-Safa H. Mohamed, Wafaa Ahmed, Einas El Shatoury, Magdy M. Mourad

\begin{tabular}{|c|c|c|c|c|c|c|c|c|c|}
\hline $\begin{array}{l}\text { 166. Naphthalene, } 1,2,3,5,6,8 \text { a-hexahydro-4,7- } \\
\text { dimethyl-1-(1-methylethyl)-, (1S-cis)- }\end{array}$ & 25.113 & - & - & - & - & - & - & - & 0.40 \\
\hline $\begin{array}{l}\text { 167. Tricyclo[4.4.0.0(2,7)]dec-8-ene-3-methanol, } \\
\text {.alpha.,.alpha.,6,8-tetramethyl-, stereoisomer. }\end{array}$ & 25.585 & 0.47 & - & - & - & - & - & - & - \\
\hline $\begin{array}{l}\text { 168. Benzene, 1,2,3-trimethoxy-5-(2-propenyl)- } \\
\text { (Elemicin). }\end{array}$ & 25.857 & - & - & - & - & 1.09 & 0.58 & - & 0.81 \\
\hline $\begin{array}{l}\text { 169. 1,6,10-Dodecatrien-3-ol, 3,7,11-trimethyl-, } \\
\text { (E)- (Nerolidol). }\end{array}$ & 26.006 & 0.55 & - & - & - & 0.79 & - & 0.32 & - \\
\hline 170. 11-Methylene-tricyclo[5.3.1.1(2,6)]dodecane. & 26.256 & 0.28 & - & - & - & - & - & - & - \\
\hline $\begin{array}{l}\text { 171. 9-Desoxo-9x-hydroxy-7-ketoingol 3,8,9,12- } \\
\text { tetraacetate. }\end{array}$ & 26.460 & - & - & - & - & - & - & - & 0.29 \\
\hline $\begin{array}{l}\text { 172. 5.alpha.-Androstane-3.alpha.,17.beta.-diol, } \\
\text { bis(pentafluoropropionate). }\end{array}$ & 26.530 & 0.26 & - & - & - & - & - & - & - \\
\hline $\begin{array}{l}\text { 173. 1H-Cycloprop[e]azulen-7-ol, decahydro- } \\
\text { 1,1,7-trimethyl-4-methylene-, [1ar- } \\
\text { (1a.alpha.,4a.alpha.,7.beta., (Spathulenol). }\end{array}$ & 26.533 & - & - & 0.55 & 0.39 & - & 0.43 & - & 1.37 \\
\hline 174. Caryophyllene oxide. & 26.693 & 3.19 & - & - & - & - & 0.27 & 0.37 & 2.76 \\
\hline $\begin{array}{l}\text { 175. 1.alpha.-(Acetoxymethyl)-7.alpha.,8.alpha.- } \\
\text { dimethyl-7-(2-(3-furyl)ethyl)bicyclo(4.4.0)dec-2- } \\
\text { ene-2-carboxylic. }\end{array}$ & 26.697 & - & 0.16 & - & - & - & - & - & - \\
\hline $\begin{array}{l}\text { 176. 1H-Cycloprop[e]azulen-4-ol, decahydro- } \\
\text { 1,1,4,7-tetramethyl-, [1aR- } \\
\text { (1a.alpha.,4.beta.,4a.beta.,7.alpha.,7a. }\end{array}$ & 26.899 & - & - & - & - & - & 0.13 & - & 0.16 \\
\hline 177. Guaiol. & 26.990 & - & - & - & 0.51 & - & - & - & - \\
\hline 178. Tetradecanal. & 27.165 & 0.30 & - & - & - & - & - & - & - \\
\hline 179. Ledol. & 27.186 & - & - & - & - & - & 0.10 & - & - \\
\hline $\begin{array}{l}\text { 180. 4aH-Cycloprop[e]azulen-4a-ol, decahydro- } \\
\text { 1,1,4,7-tetramethyl-, [1aR- } \\
\text { (1a.alpha.,4.beta.,4a.beta.,7.alpha.,7a.b e1t0a.9. }\end{array}$ & 27.192 & - & - & - & - & - & - & - & 0.37 \\
\hline 181. 2,5,9-Trimethylcycloundeca-4,8-dienone. & 27.336 & 0.26 & - & - & - & - & - & - & - \\
\hline 182. alpha.-Cadinol. & 28.068 & - & - & - & - & - & - & - & 0.49 \\
\hline $\begin{array}{l}\text { 183. 5.beta.,6.beta.-Epoxy-7.alpha.- } \\
\text { bromocholestan-3.beta.-ol. }\end{array}$ & 28.150 & - & - & - & - & - & - & - & 0.20 \\
\hline
\end{tabular}


Al-Safa H. Mohamed, Wafaa Ahmed, Einas El Shatoury, Magdy M. Mourad

\begin{tabular}{|c|c|c|c|c|c|c|c|c|c|}
\hline 184. Tetrahydrosarsasapogenintribenzoate. & 28.300 & - & - & - & - & 0.29 & - & - & - \\
\hline $\begin{array}{l}\text { 185. 2-Pyrrol[6-(1-methoxycarbonyl-2-phenyl- } \\
\text { ethylcarbamoyl)-pyridine-2-carbonyl]- } \\
\text { aminomorpho-3-phenyl- propio. }\end{array}$ & 28.310 & - & - & - & - & - & - & - & 0.67 \\
\hline $\begin{array}{l}\text { 186. 2-Naphthalenemethanol, decahydro- } \\
\text {.alpha.,.alpha.,4a-trimethyl-8-methylene-, [2R- } \\
\text { (2.alpha.,4a.alpha.,8a. }\end{array}$ & 28.305 & - & - & - & - & - & 0.12 & - & - \\
\hline 187. alpha.-Cadinol. & 28.367 & - & - & - & - & - & 0.21 & - & 1.67 \\
\hline $\begin{array}{l}\text { 188. } 1 \mathrm{H}-\text { Cycloprop[e]azulen-4-ol, decahydro- } \\
\text { 1,1,4,7- tetramethyl-, [1aR- } \\
\text { (1a.alpha.,4.beta.,4a.beta.,7.alpha. }\end{array}$ & 28.373 & - & - & - & - & 0.56 & - & - & - \\
\hline 189. Pseudosarsasapogenin diacetate. & 28.374 & 0.22 & - & - & - & - & - & - & - \\
\hline 190. alpha.-ylangene. & 28.475 & 0.19 & - & - & - & - & - & - & - \\
\hline $\begin{array}{l}\text { 191. 5-Azulenemethanol, 1,2,3,3a,4,5,6,7- } \\
\text { octahydro-.alpha.,.alpha.,3,8-tetramethyl-, [3S- } \\
\text { (3.alpha.,3a.beta.,5.alpha. }\end{array}$ & 28.688 & - & - & - & 0.25 & - & - & - & - \\
\hline 192. 2,5-Octadecadiynoic acid, methyl ester. & 29.144 & - & - & - & - & 0.55 & - & - & - \\
\hline 193. Carotol. & 29.278 & - & - & - & - & - & 0.21 & - & 0.81 \\
\hline 194. Cycloartanol. & 31.383 & - & - & - & - & - & - & - & 0.13 \\
\hline 195. Cycloisolongifolene, 8,9-dehydro-9-formyl- & 33.328 & - & - & - & - & 0.24 & - & - & - \\
\hline $\begin{array}{l}\text { 196. Bicyclo[6.1.0]nonane, 9-bromo-9-methyl-, } \\
\text { (1.alpha.,8.alpha.,9.alpha.)- }\end{array}$ & 39.120 & - & - & - & - & - & - & - & 0.46 \\
\hline 197. Cyclononasiloxane, octadecamethyl- & 56.430 & - & - & - & - & - & - & - & 0.13 \\
\hline
\end{tabular}

